\section{Butterfly species diversity, relative abundance and status in Tropical Forest Research Institute, Jabalpur, Madhya Pradesh, central India}

\author{
Ashish D. Tiple \\ Forest Entomology Division, Tropical Forest Research Institute, \\ Jabalpur, Madhya Pradesh 482021, India \\ Deparment of Zoology, Vidyabharati College Seloo, Wardha, \\ Maharashtra 442104, India \\ Email: ashishdtiple@yahoo.co.in
}

The Tropical Forest Research Institute (TFRI) Jabalpur is one of nine institutes under the Indian Council of Forestry Research and Education. It lies on the bank of the Gour River on Mandla Road (79059'23.50"E \& $21^{\circ} 08^{\prime} 54.30^{\prime \prime} \mathrm{N}$ ) about $10 \mathrm{~km}$ southeast of Jabalpur. The campus is spread over an area of 109 ha amidst picturesque surroundings (Image 1); semi-arid with mean annual precipitation of $1358 \mathrm{~mm}$. The campus is surrounded by agricultural fields with rural habitation. The water reservoir and the vegetation planted around the institute have created a very good habitat and source of attraction for many faunal species like insects, reptiles, birds and mammals (Tiple et al. 2010). The area has trees, shrubs, grasslands and small hills.

Butterflies are generally regarded as one of the best taxonomically studied groups of insects (Robbins

\author{
Date of publication (online): 26 July 2012 \\ Date of publication (print): 26 July 2012 \\ ISSN $0974-7907$ (online) | 0974-7893 (print) \\ Editor: B.A. Daniel \\ Manuscript details: \\ Ms \# 02656 \\ Received 23 December 2010 \\ Final received 13 April 2012 \\ Finally accepted 22 June 2012
}

Citation: Tiple, A.D. (2012). Butterfly species diversity, relative abundance and status in Tropical Forest Research Institute, Jabalpur, Madhya Pradesh, central India. Journal of Threatened Taxa 4(7): 2713-2717.

Copyright: (c) Ashish D. Tiple 2012. Creative Commons Attribution 3.0 Unported License. JoTT allows unrestricted use of this article in any medium for non-profit purposes, reproduction and distribution by providing adequate credit to the authors and the source of publication.

Acknowledgements: Thanks to Dr. K.C. Joshi and Dr. Nitin Kulkarni, Senior Scientist, Tropical Forest Research Institute, Jabalpur for valuable suggestions and providing facilities. I am also thankful to Mr. Sanjay Paunikar, for his assistance during the field survey.
\& Opler 1997), yet even in genera containing very common and widespread species, our

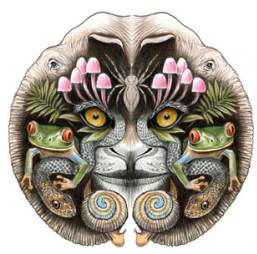
understanding of true species diversity may prove to be startlingly below common expectation (Ackery 1987; Tiple \& Khurad 2009; Willmott et al. 2001).

Butterflies are an important aspect of ecosystems for they interact with plants as pollinators and herbivores (Tiple et al. 2006). Butterflies are also good indicators of environmental changes as they are sensitive to habitat degradation and climate changes (Kunte 2000).

The Indian subcontinent hosts about 1,504 species of butterflies (Tiple 2011) of which peninsular India and the Western Ghats host 351 and 334 species respectively. In Madhya Pradesh and Vidarbha of central India 177 species of butterfly species have been documented (D’Abreu 1931).

Subsequent works and fauna volumes include several species from Madhya Pradesh and Chhattisgarh (Evans 1932; Talbot 1939, 1947; Wynter-Blyth 1957). In the recent past, several researchers have studied butterflies from some districts and conservation areas of Madhya Pradesh and Chhattisgarh (Singh 1977; Gupta 1987; Chaudhury 1995; Chandra et al. 2000a,b; 2002; Singh \& Chandra 2002; Siddiqui \& Singh 2004; Chandra 2006). Chandra et al. (2007) recorded 174 species of butterflies belonging to eight families from Madhya Pradesh and Chhattisgarh.

The present study was started to examine the diversity of butterflies from TFRI Campus, since there was no known published checklist of butterflies in the TFRI campus.

\section{Materials and Methods}

The findings presented here are based on a bi-weekly random survey carried out from June 2008 to May 2009 at the TFRI campus. The observations were made from $0800 \mathrm{hr}$ to $1100 \mathrm{hr}$, which is a peak time for butterfly activity. Butterflies were Primarily identified directly in the field or, in difficult cases, following capture or photography. In critical conditions, specimens were collected only with handheld aerial sweep nets. Each specimen was placed in a plastic bottle and carried to the laboratory for further identification with the help of a field guide (Wynter-Blyth 1957; Kunte 2000; Haribal 2002). All scientific names followed in the present 


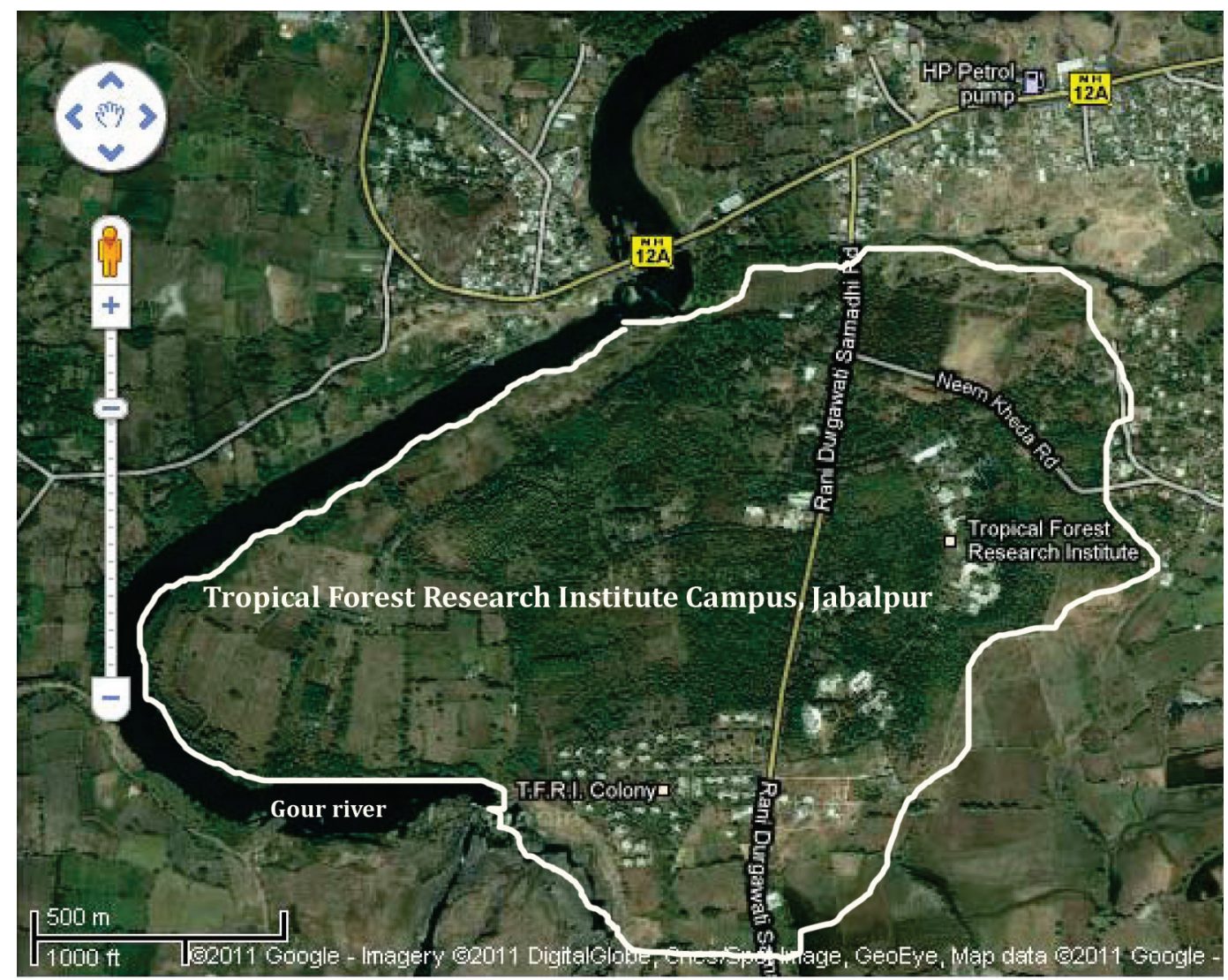

Image 1. Satellite overview map of study locality

study are in accordance to Varshney (1983). The observed butterflies were categorized in five categories on the basis of their abundance in the TFRI campus. $\mathrm{VC}$ - very common (> 100 sightings), C - common (50100 sightings), NR - not rare (15-50 sightings), $\mathrm{R}$ - rare ( $2-15$ sightings), VR - very rare (1-2 sightings) (Tiple et al. 2006).

\section{Results and Discussion}

A total of 66 species of butterflies belonging to 47 genera and five families viz.,-Papilionidae (5 species), Pieridae (9 species), Nymphalidae (25 species), Lycaenidae (18 species) and Hesperiidae ( 9 species) were recorded. Among these 65 species, 24 (37\%) were commonly occurring, 16 (24\%) were very common, 2 $(3 \%)$ were not rare, $18(27 \%)$ were rare and $6(9 \%)$ were very rare. The observed species and their status on the TFRI campus is presented in Table 1. Five of the recorded species (Table 1) come under the Indian Wildlife (Protection) Act 1972 (Kunte 2000; Gupta \& Mondal 2005).

Among the 66 species of butterflies, Papilio demoleus, Catopsilia pomona, Eurema hecabe, Danaus chrysippus, Euploea core, Hypolimnas misippus, Junonia lemonias, Melanitis leda, Tirumala limniace, Catochrysops strabo, Prosotas nora, Borbo cinnara, Pelopidas mathias were present throughout the year (January-December), whereas 53 species were observed only from June-July till the beginning of summer (April-May). Increasing species abundance from the beginning of the monsoons (June-July) till early winter (August-November) and decline in species abundance from late winter (January-February) to the end of summer (Fig. 1) have also been reported by Tiple et al. (2007) and Tiple \& Khurad (2009) in similar climatic conditions in this region of central India. They further demonstrated that most of the species were noticeably absent in the disturbed and human impacted sites (gardens, plantation and grassland) and there was no occurrence of unique species in moderately disturbed areas comparable to those of less disturbed wild areas. The present study site is in constant disturbance due to the cutting of grasses, shrubs and trees for landscaping which may be the reason for the overall reduction of the 
Table 1. List of butterflies recorded from TFRI Campus together with common name and status

\begin{tabular}{|c|c|c|c|}
\hline Common name & Scientific name & $\begin{array}{l}\text { Occurrence } \\
\text { (months) }\end{array}$ & Status \\
\hline \multicolumn{4}{|l|}{ Papilionidae (5) } \\
\hline Spot Swordtail & Graphium nomius (Esper) & $4-7$ & $\mathrm{R}$ \\
\hline Common Rose & Pachliopta aristolochiae (Fabricius) & $7-3$ & NR \\
\hline Crimson Rose & Pachliopta hector (Linnaeus)* & $8-1$ & $\mathrm{R}$ \\
\hline Lime & Papilio demoleus Linnaeus & $1-12$ & VC \\
\hline Common Mormon & Papilio polytes Linnaeus & $7-2$ & C \\
\hline \multicolumn{4}{|l|}{ Pieridae (9) } \\
\hline Pioneer & Anaphaeis aurota (Fabricius) & $11-2$ & $\mathrm{R}$ \\
\hline Lemon Emigrant & Catopsilia pomona (Fabricius) & $1-12$ & VC \\
\hline Mottled Emigrant & Catopsilia pyranthe (Linnaeus) & $7-12$ & $\mathrm{C}$ \\
\hline Common Gull & Cepora nerissa (Fabricius) & $7-2$ & $\mathrm{R}$ \\
\hline Common Jezebel & Delias eucharis (Linnaeus) & $9-3$ & C \\
\hline Three-Spot Grass Yellow & Eurema blanda (Boisduval) & $7-11$ & $\mathrm{R}$ \\
\hline Common Grass Yellow & Eurema hecabe (Linnaeus) & $1-12$ & VC \\
\hline Spotless Grass Yellow & Eurema laeta (Boisduval) & $4-8$ & $\mathrm{C}$ \\
\hline Psyche & Leptosia nina (Fabricius) & $11-12$ & $\mathrm{R}$ \\
\hline \multicolumn{4}{|l|}{ Nymphalidae (25) } \\
\hline Tawny Coster & Acraea violae (Fabricius) & $6-12$ & C \\
\hline Angled Castor & Ariadne ariadne (Linnaeus) & $6-11$ & $\mathrm{C}$ \\
\hline Black Rajah & Charaxes solon (Fabricius) & $8-9$ & VR \\
\hline Painted Lady & Cynthia cardui (Linnaeus) & $9-3$ & C \\
\hline Plain Tiger & Danaus chrysippus (Linnaeus) & $1-12$ & VC \\
\hline Striped Tiger & Danaus genutia (Cramer) & $9-6$ & VC \\
\hline Common Indian Crow & Euploea core (Cramer)* & $1-12$ & VC \\
\hline Common Baron & Euthalia aconthea (Cramer) & 6 & VR \\
\hline Baronet & Euthalia nais (Forster) & $8-2$ & VC \\
\hline Great Eggfly & Hypolimnas bolina (Linnaeus) & $6-1$ & $\mathrm{C}$ \\
\hline Danaid Eggfly & Hypolimnas misippus (Linnaeus)* & $1-12$ & C \\
\hline Peacock Pansy & Junonia almanac (Linnaeus) & $6-1$ & C \\
\hline Grey Pansy & Junonia atlites (Linnaeus) & $8-3$ & $\mathrm{R}$ \\
\hline Yellow Pansy & Junonia hierta (Fabricius) & 2 & VR \\
\hline Chocolate Pansy & Junonia iphita (Cramer) & $6-11$ & C \\
\hline Lemon Pansy & Junonia lemonias (Linnaeus) & $1-12$ & VC \\
\hline Blue Pansy & Junonia orithya (Linnaeus) & $9-3$ & C \\
\hline Commander & Limenitis procris (Cramer) & $9-10$ & $\mathrm{R}$ \\
\hline Common Evening Brown & Melanitis leda (Linnaeus) & $1-12$ & VC \\
\hline Dark Branded Bushbrown & Mycalesis mineus (Linnaeus) & $6-11$ & C \\
\hline Common Bushbrown & Mycalesis perseus (Fabricius) & $6-3$ & VC \\
\hline Common Sailer & Neptis hylas (Linnaeus) & $7-12$ & VC \\
\hline Common Leopard & Phalanta phalantha (Drury) & $6-1$ & VC \\
\hline Blue Tiger & Tirumala limniace (Cramer) & $1-12$ & VC \\
\hline Common Five Ring & Ypthima baldus (Fabricius) & $6-10$ & VR \\
\hline \multicolumn{4}{|l|}{ Lycaenidae (18) } \\
\hline Plum Judy & Abisara echerius (Stoll) & $9-10$ & $\mathrm{R}$ \\
\hline Large Oakblue & Arhopala amantes (Hewitson) & $10-2$ & $\mathrm{R}$ \\
\hline Common Pierrot & Castalius rosimon (Fabricius) & $6-7$ & $\mathrm{R}$ \\
\hline
\end{tabular}




\begin{tabular}{|c|c|c|c|}
\hline Common name & Scientific name & $\begin{array}{l}\text { Occurrence } \\
\text { (months) }\end{array}$ & Status \\
\hline Forget-Me-Not & Catochrysops strabo (Fabricius) & $1-12$ & C \\
\hline Plains Cupid & Chilades pandava (Horsfield) & $6-2$ & C \\
\hline Small Cupid & Chilades parrhasius (Butler) & $10-11$ & $\mathrm{R}$ \\
\hline Lime Blue & Chilades laius (Stoll) & $7-9$ & $\mathrm{C}$ \\
\hline Eastern grass Jewel & Chilades pulti Kollar & $6-2$ & $\mathrm{C}$ \\
\hline Gram Blue & Euchrysops cnejus (Fabricius)* & $7-12$ & NR \\
\hline Dark Cerulean & Jamides bochus (Stoll) & $8-9$ & VR \\
\hline Pea Blue & Lampides boeticus (Linnaeus)* & $9-2$ & C \\
\hline Zebra Blue & Leptotes plinius Fabricius & $7-9$ & C \\
\hline Common Line Blue & Prosotas nora (C. Felder) & $1-12$ & C \\
\hline Pale Grass Blue & Psuedozizeeria maha (Kollar) & 7 & $\mathrm{R}$ \\
\hline Common Silverline & Spindasis vulcanus (Fabricius) & $6-1$ & VC \\
\hline Rounded Pierrot & Tarucus nara Kollar & $6-12$ & C \\
\hline Lesser Grass Blue & Zizina otis (Fabricius) & $6-11$ & $\mathrm{R}$ \\
\hline Tiny Grass Blue & Zizula hylax (Fabricius) & $6-8$ & $\mathrm{R}$ \\
\hline \multicolumn{4}{|l|}{ Hesperiidae (9) } \\
\hline Brown Awl & Badamia exclamationis (Fabricius) & $6-10$ & VC \\
\hline Rice Swift & Borbo cinnara (Wallace) & $1-12$ & C \\
\hline Blank Swift & Caltoris kumara (Moore) & $8-10$ & $\mathrm{R}$ \\
\hline Tricolour Pied Flat & Coladenia indrani (Moore) & $6-9$ & $\mathrm{C}$ \\
\hline Common Banded Awl & Hasora chromus (Cramer) & $6-10$ & VC \\
\hline Dark Palm Dart & Telicota ancilla (Herrich-Schaffer) & $8-12$ & $\mathrm{R}$ \\
\hline Pale Palm Dart & Telicota colon (Fabricius) & $8-9$ & VR \\
\hline Small-Branded Swift & Pelopidas mathias (Fabricius) & $1-12$ & C \\
\hline Indian Skipper & Spialia galba (Fabricius) & $8-10$ & $\mathrm{R}$ \\
\hline
\end{tabular}

VC - very common (> 100 sightings); C - common (50-100 sightings); NR - not rare (15-50 sightings); R - rare (2-15 sightings); VR - very rare (1-2 sightings); * - Listed in Indian Wildlife (Protection) Act 1972

number of species.

The findings of the present study underline the importance of institutional estates as a preferred habitat for butterflies. If the landscaping and maintenance of gardens are carefully planned, the diversity of butterflies may increase in the TFRI campus providing a rich ground for butterfly conservation as well as for research.

\section{REFERENCE}

Ackery, P.R. (1987). Diversity and phantom competition in African acraeine butterflies. Biological Journal of the Linnean Society 30: 291-297.

Chandra, K., R.M. Sharma, A. Singh \& R.K. Singh (2007). A checklist of butterflies of Madhya Pradesh and Chhattisgarh States, India. Zoos' Print Journal 22(8): 2790-2798.

Chandra, K., R.K. Singh \& M.L. Koshta (2000a). On a collection of butterflies (Lepidoptera: Rhopalocera) from Sidhi District, Madhya Pradesh, India. Records of Zoological Survey of India 98(4): 11-23.

Chandra, K., R.K. Singh \& M.L. Koshta (2000b). On a collection of Butterfly fauna from Pachmarhi Biosphere Reserve. Proceedings of National Seminar on Biodiversity Conservation 8 Management with Special Reference on Biosphere Reserve, EPCO, Bhopal, November, 72-77pp.

Chandra, K., L.K. Chaudhary, R.K. Singh \& M.L. Koshta (2002). Butterflies of Pench Tiger Reserve, Madhya Pradesh. Zoos' Print Journal 17(10): 908-909.

Chandra, K. (2006). The Butterflies (Lepidoptera: Rhopalocera) of Kangerghati National Park (Chhattisgarh). Advancement in Indian Entomology: Productivity and Health, Vol. II, 8388pp.

Chaudhury, M. (1995). Insecta: Lepidoptera, Fauna of Conservation Area: Fauna of Indravati Tiger Reserve. Zoological Survey of India 6: 45-52.

D'Abreu, E. A. (1931). The Central Provinces Butterfly List. Records of the Nagpur Museum Number VII, Government Printing City Press, 39pp. 


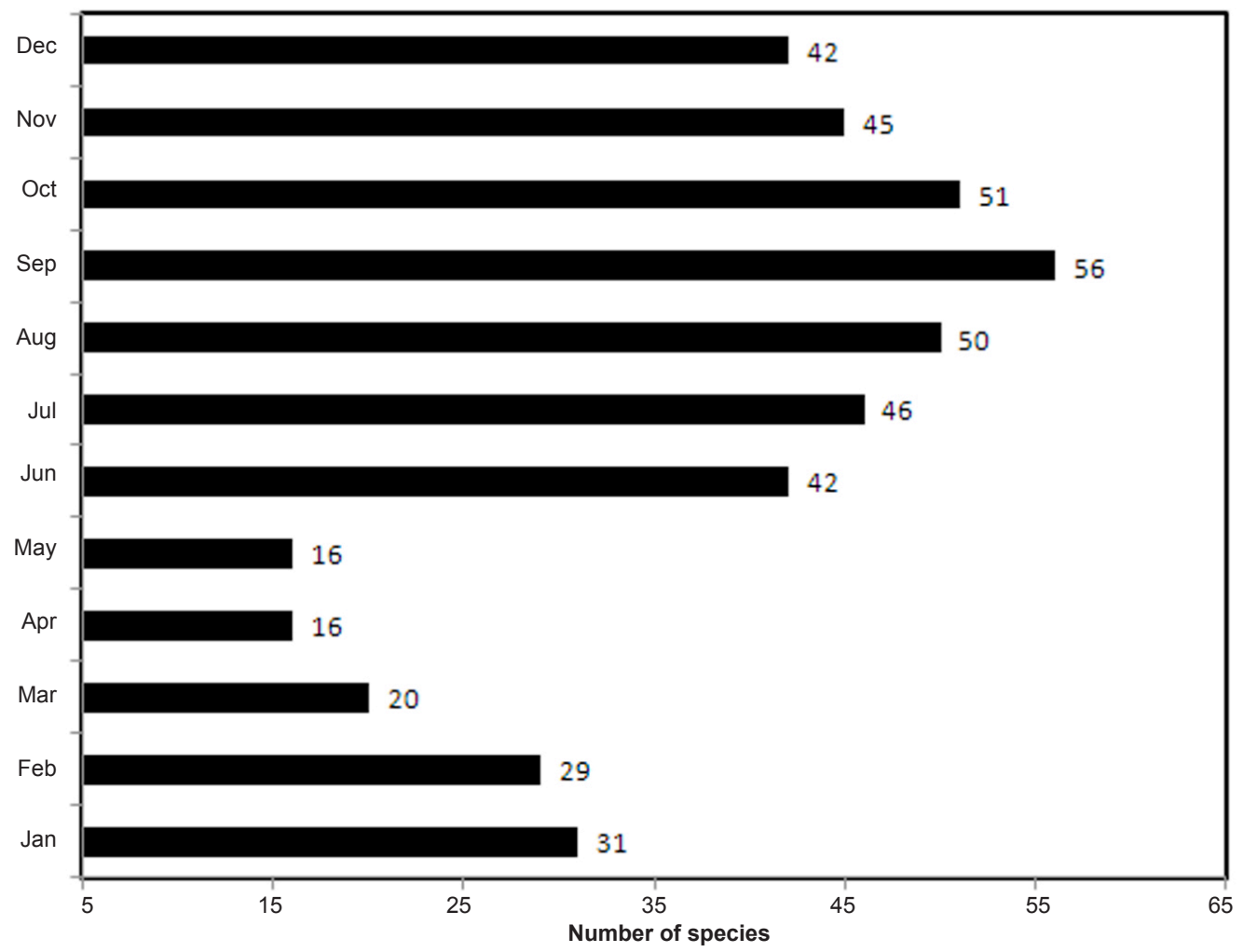

Figure 1. The variations of species composition throughout the year in Tropical Forest Research Institute, Jabalpur

Evans, W.H. (1932). The Identification of Indian Butterflies. 2nd Edition. Bombay Natural History Society, Mumbai, 454pp.

Gupta, I.J. \& D.K. Mondal (2005). Red Data Book-Part II: Buttrflies of India. Zoological Society of India, Kolkata, $535 \mathrm{pp}$.

Gupta, I.J. 8 J.P.N. Shukla (1987). Butterflies from Bastar district (Madhya Pradesh, India). Records of Zoological Survey of India, Occasional Paper 106: 1-74.

Haribal, M. (1992). The Butterflies of Sikkim Himalaya and their Natural History. Sikkim Nature Conservation Foundation (SNCF), Sikkim, 217pp.

Kunte, K. (2000). Butterflies of Peninsular India. Universities Press (Hyderabad) and Indian Academy of Sciences (Bangalore), 254pp.

Siddiqui, A. \& S.P. Singh (2004). A checklist of the butterfly diversity of Panna Forest (M.P). National Journal of Life Sciences 1(2): 403-406.

Singh, R.K. \& K. Chandra (2002). An inventory of butterflies of Chhattisgarh. Journal of Tropical Forestry 18(1): 67-74.

Singh, R.K. (1977). On a collection of butterflies (Insecta) from Bastar district, Madhya Pradesh, India. Newsletter Zoological Survey of India 3(5): 323-326.

Talbot, G. (1939). The Fauna of British India including Ceylon and Burma. Butterflies. Today and Tomorrow's Printers and Publishers, New Delhi, 600pp.

Talbot, G. (1947). The Fauna of British India including Ceylon and Burma. Butterflies. Today and Tomorrow's Printers and Publishers, New Delhi, 506pp.
Tiple, A.D. (2011). Butterflies of Vidarbha region Maharashtra, India; a review with and implication for conservation. Journal of Threatened Taxa 3(1): 1469-1477.

Tiple, A.D., N. Kulkarni, S. Paunikar \& K.C. Joshi (2010). Avian fauna of tropical forest research institute Jabalpur, Madhya Pradesh, India. Indian Journal of Tropical Biodiversity 18(1): 1-9

Tiple, A.D. \& A.M. Khurad (2009). Butterfly species diversity, habitats and seasonal distribution in and around Nagpur City, central India. World Journal of Zoology 4(3): 153-162.

Tiple, A.D., V.P. Deshmukh \& R.L.H. Dennis (2006). Factors influencing nectar plant resource visits by butterflies on a university campus: implications for conservation. Nota Lepidopteralogica 28: 213-224.

Tiple, A.D., A.M. Khurad \& R.L.H. Dennis (2007). Butterfly diversity in relation to a human-impact gradient on an Indian university campus. Nota Lepidopteralogica 30(1): 179-188.

Varshney, R.K. (1983). Index Rhopalocera indica part II. Common names of butterflies from India and neighbouring countries. Records of the Zoological Survey of India. Occasional Paper no. 47: 1-49.

Willmott, K.R., J.P.W. Hall \& G. Lamas (2001). Systematics of Hypanartia (Lepidoptera: Nymphalidae: Nymphalinae), with a test for geographical speciation mechanisms in the Andes. Systematic Entomology 26: 369-399.

Wynter-Blyth, M.A. (1957). Butterflies of the Indian Region. Bombay Natural History Society, 523pp. 